\title{
CERTAIN HAEMATOLOGICAL AND BIOCHEMICAL PROFILES OF A WHITE TIGERESS (PANTHERA TIGRIS LINNAEUS) SUFFERING FROM TRYPANOSOMIASIS
}

\author{
S. Singh ${ }^{1}$, C.Singh ${ }^{2}$, A. Kumar ${ }^{3}$, K.K. Sinha ${ }^{4}$, and P.C. Mishra ${ }^{5}$ \\ ${ }^{1}$ J.A.R.O. Biological Product. L.R.S. Patna, Bihar 800014, India \\ ${ }^{2}$ Associate Professor, Department of Veterinary, Physiology, Bihar Veterinary College, Patna, Bihar 800014, India \\ ${ }^{3}$ T.V.O., Palkot, Gumla, Bihar, India \\ ${ }^{4}$ Ex-Veterinary Surgeon, Sanjay Gandhi Biological Park, Patna, Bihar 800014, India \\ ${ }^{5}$ Ex-Director, Sanjay Gandhi Biological Park, Patna, Bihar 800014, India
}

\section{Introduction}

The incidence of trypanosomiasis in wild animals like tigers, leopards and jaguars has been reported (Alwar, 1953; Sinha et al., 1971). Most of these reports contain information on clinical symptoms and post-mortem lesions (Sinha et al., 1971). The information on circulating hematological and biochemical profiles of wild carnivores suffering from trypanosomiasis are meager to relate with clinical symptoms.

The present study includes a detailed observation on clinical symptoms as well as hemograms and blood chemistry profile of a white tigeress (Vaisali, 8 years old) maintained in captivity at the Sanjay Gandhi Zoological Park, Patna. The animal conceived when it was seven years of age but aborted at full term. Following abortion it developed health problems like reduced appetite, gradual emaciation, oedema in the abdominal region, slow and progressive dullness and depression. The body temperature recorded since the observation of clinical symtoms was normal $\left(102^{\circ} \mathrm{F}\right)$. The fecal samples were negative of parasitic infestation. The animal was treated with supportive drug vitamin B Complex and liver extract during intial stages. During the course of the treatment the animal was also fed with protein-rich diet along with mineral mixture. The condition deteriorated gradually with exhibition of some more pronounced abnormal symptoms like staggering gait, weakness in hind quarters, muscular tremors, bilateral mucus discharge from eyes, circling movement, dashing against objects and frequent urination. The animal soon ended up in lateral recumbancy.

\section{Materials and Methods}

The animal was then secured in a squeeze cage and about $15 \mathrm{ml}$ blood was collected (from the dorsal branch of median saphenous vein in the hind leg at about the level of the knee). Blood clotting time (BCT), total erythrocyte count (TEC), total leucocyte count (TLC), differential leucocyte count (DLC) were con- ducted using fresh blood, while packed cell volume (PCV) was estimated from heparinized blood as described by Schalm et al. (1975). Serum calcium and inorganic phosphorus, ESR and hemoglobin were estimated by the method described by Kolmer $e t$ al. (1969). The concentration of total serum protein, albumin and globulins were estimated as per the method discribed by Varley (1975). Mean corpuscular volume (MCV), mean corpuscular hemoglobin $(\mathrm{MCH})$ and mean corpuscular hemoglobin concentration (MCHC) were calculated by the formula as described by Swenson and Reece (1996). Blood smear was stained by Geimsa stain (Schalm et al., 1975) for differential leukocytic count and examination of protozoal infection. The hematological and biochemical profiles recorded have been presented in Table 1.

Table 1. Hematological and biochemical profile of a white tigeress suffering from Trypanosomiasis.

\begin{tabular}{|c|c|c|c|}
\hline Parameters & Value & Parameter & Value \\
\hline $\begin{array}{l}\text { Blood clotting } \\
\text { time }\end{array}$ & 9 minutes & $\begin{array}{l}\text { Differencial } \\
\text { leukocytic count }\end{array}$ & \\
\hline Haemoglobin & $10.5 \mathrm{~g} / \mathrm{dl}$ & (i)Neutrophil & $76 \%$ \\
\hline $\begin{array}{l}\text { Mean corpuscular } \\
\text { haemoglobin }\end{array}$ & $18.32 \mathrm{~g}$ & (ii)Lymphocyte & $19 \%$ \\
\hline $\begin{array}{l}\text { Mean corpuscular } \\
\text { haemoglobin } \\
\text { concentration }\end{array}$ & $32.81 \mathrm{~g} / \mathrm{dl}$ & $\begin{array}{l}\text { (iii)Monocyte } \\
\text { (iv)Eosinophil }\end{array}$ & $\begin{array}{l}01 \% \\
04 \%\end{array}$ \\
\hline $\begin{array}{l}\text { Mean corpuscular } \\
\text { volume }\end{array}$ & $55.84 u^{3}$ & Serum calcium & $11.2 \mathrm{mg} / \mathrm{dl}$ \\
\hline $\begin{array}{l}\text { Erythrocyte } \\
\text { sedimentation rate }\end{array}$ & $76 \mathrm{~mm} / \mathrm{hr}$ & $\begin{array}{l}\text { Serum inorganic } \\
\text { phosphorus }\end{array}$ & $3.8 \mathrm{mg} / \mathrm{dl}$ \\
\hline $\begin{array}{l}\text { Packed cell } \\
\text { volume }\end{array}$ & $32 \%$ & $\begin{array}{l}\text { Total protein } \\
\text { Serum albumin }\end{array}$ & $\begin{array}{l}7.9 \mathrm{~g} / \mathrm{dl} \\
3.1 \mathrm{~g} / \mathrm{dl}\end{array}$ \\
\hline $\begin{array}{l}\text { Total erytrocyte } \\
\text { count }\end{array}$ & $5.73 \times 10^{6} / \mathrm{ul}$ & Serum globulin & $4.8 \mathrm{~g} / \mathrm{dl}$ \\
\hline $\begin{array}{l}\text { Total leukocyte } \\
\text { count }\end{array}$ & $9.1 \times 10^{3} / \mathrm{ul}$ & & \\
\hline
\end{tabular}




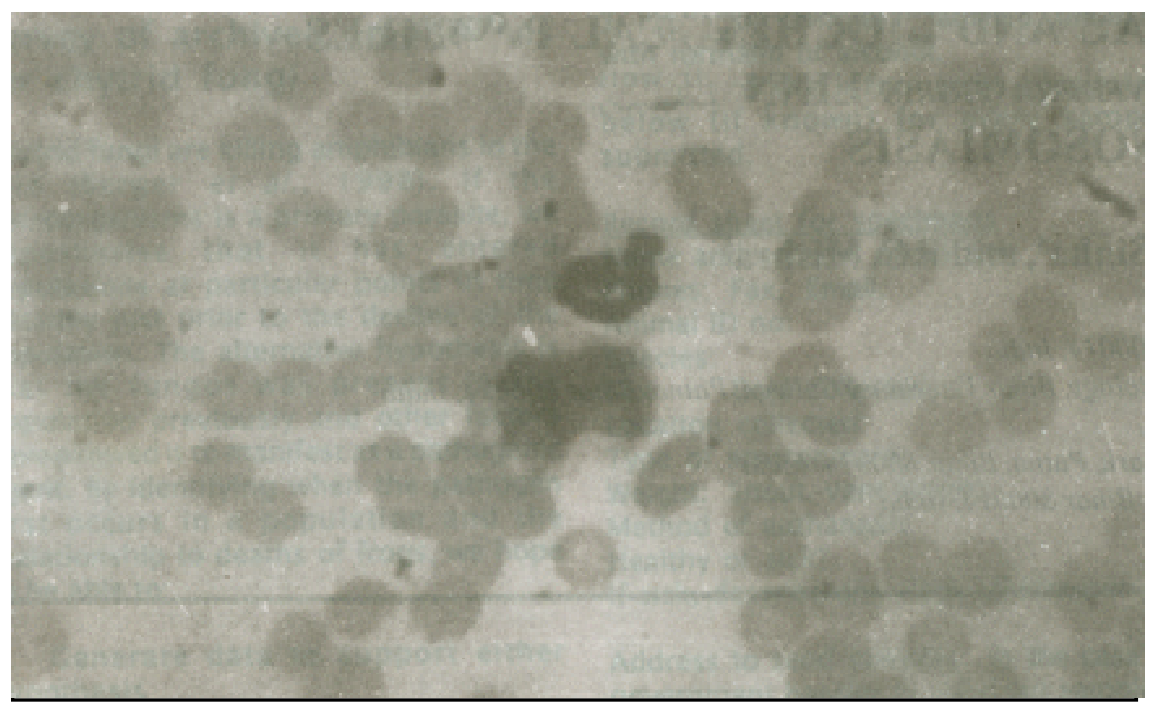

nosomiasis by blood smear but did not respond to the treatment and it died within 72 hours of the initiation of treatment. As the physical condition of this animal was deteriorating over two months, it could be assumed that this animal was having chronic case of trypanosomiasis.

The postmortem examination revealed no change in the size of liver, spleen and kidney. No peticheal haemorrhages were observed in liver, spleen and kidneys. Though such lesions were also not observed in one male tiger, one female leopard and one male leopard that died due to trypanosome infection showed peticheal hemorrhage of liver, spleen and kidney (Sinha et al., 1971).

\section{Results and Discussion}

The examination of blood smear revealed heavy infection with trypanosomes (Figure 1). The species of trypanosoma could not be determined clearly because immunodiagnostic test was not conducted.

The examination of blood for different parameters indicated that the BCT, MCH, MCHC, TLC, DLC, serum calcium, serum inorganic phosphorus, total serum protein, serum albumin and serum globulin values recorded in this tigeress were similar to the values recorded for above parameters in healthy tigers and leopardess (Singh, 1998) and Asiatic lioness (Christi et al., 1998). However, the $\mathrm{Hb}$ concentration, TEC, PCV and MCV were lower than the values of respective parameters recorded in healthy captive tigers (Singh, 1998) and Asiatic lioness (Christi et al., 1998). The similar lower values of Hb, PCV, and TEC (Verma, 1973; Razzaque, 1976; Roy, 1987) and MCV (Razzaque, 1976; Roy, 1987) were reported in trypanosome infection in buffaloes. The reduced appetite, gradual emaciation, dullness and oedema of abdominal region observed in this animal agreed with similar clinical symptoms shown by buffaloes suffering from trypanosomiasis (Verma, 1973; Losos, 1980). Anaemia, ocular mucus discharge and weakness of hind quarter as observed in this animal has also been reported in acute as well as chronic form of trypanosomiasis in cattle (Losos, 1980). Other symptoms observed in this animal was also reported in cattle and buffaloes suffering from Trypanosoma evansi (Singh, 1977). However, the ESR value recorded in this animal was higher than the healthy tigers and leopards maintained in the Zoological Park (Singh, 1998).

The microcytic normochromic anaemia recorded in this animal was similar to the observation recorded in buffalo calves (Singh, 1983). The animal was treated with Berenil (Hoechst India Ltd.) and other supportive treatment just after the diagnosis of trypa-

\section{Acknowledgement}

Authors are highly thankful to the Principal, Bihar Veterinary College, Patna, for providing facilities to carry out this investigation.

\section{References}

Alwar, V.S. (1953). Studies on Surra in Madras. M.V.Sc. Thesis, Madras University, Madras, Tamil Nadu.

Christi, K.S., R.H. Sabapara and V.P. Vadodaria (1998). Certain haematological and biochemical profiles in Asiatic lioness (Panthera leo persica). Zoos' Print XIII, 17-20.

Kolmer, J.A., E.H. Spaulding and H.W. Robinson (1969). "Approved laboratory technic" Fifth ed. (Indian ed).

Losos, G.J. (1980). Diseases caused by Trypanosoma evansi. A review. Veterinary Research Communications 4, 165-181.

Razzaque, A. (1976). Studies on experimental trypanosomiasis (Surra) in buffalo calves. M.V.Sc. thesis, Rajendra Agricultural University, Bihar.

Schalm, O.W., N.C. Jain and J.E. Carroll (1975). Veterinary Hematology, 3rd ed. Lea and febiger, Philadelphia.

Singh, B.P. (1983). Studies on bovine trypanosomiasis with special reference to diagnosis and therapy. $\mathrm{Ph} . \mathrm{D}$. Thesis, Punjab Agricultural University, Ludhiana, India.

Singh, C (1977). Clinical trial of Berenil (Hoechst) against trypanosomiasis in cattle and buffaloes. Indian Veterinary Journal 54: 452.

Singh, S (1998). Studies on hematology and certain blood constituents of tigers and leopards kept in captivity. M.V.Sc. thesis, Rajendra Agricultural University, Pusa, Bihar, India.

Sinha, P.K., G.S. Mukherjee., M.S. Das and R.K. Lahiri (1971). Out break of trypanosomiasis evansi amongst tigers and jaguars in the Zoological garden, Calcutta. Indian Veterinary Journal 48: 306-310.

Swenson, M.J. and W.O. Reece (1996). Duke's physiology of Domestic animals, 11th ed. 1st Indian reprint, panima publishing corporation New Delhi and Bangalore.

Varley, H (1975). Practical clinical Biochemistry, 4th ed. (Indian edn.) Arnold-Heineman publishers (India) Pvt. Ltd.

Verma. B.B. (1973). Studies on some aspects of trypanosomiasis (Surra) in cattle and buffaloes. Ph.D. thesis, Haryana Agricultural University, Hissar, India. 